\title{
elsevier_APEN_7411
}

\section{Development of the Turgo Impulse turbine: Past and Presentpresent}

D.S. Benzon ${ }^{2}$

G.A. Aggidis $\mathbf{s}^{a, *}$

g.aggidis@lancaster.ac.uk

J.S. Anagnostopoulos ${ }^{\mathrm{b}}$

aLancaster University Renewable Energy Group and Fluid Machinery Group, Engineering Department, Engineering Building, Bailrigg, Lancaster, Lancs LA1 4YR, UK

bSchool of Mechanical Engineering, National Technical University of Athens, Athens, Greece

${ }^{*}$ Corresponding author. Tel.: +44 1524593052, mobile: +44 7813697630 .

\section{Abstract}

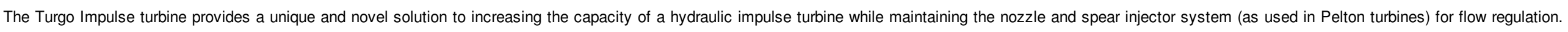
This has produced a turbine which operates in the higher flow ranges usually reserved for Francis machines while maintaining a relatively flat efficiency curve, characteristic of impulse machines.

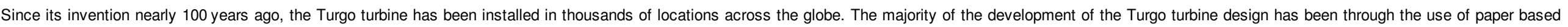

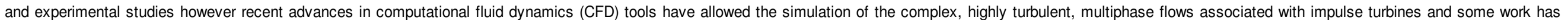

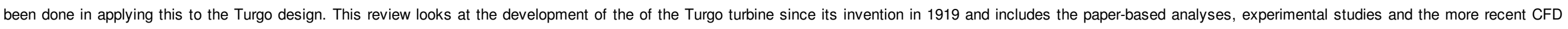
analyses carried out on the design.

Keywords: Turgo turbines; Impulse turbines; Hydropower; Hydraulic design; Numerical modelling

\section{Introduction}

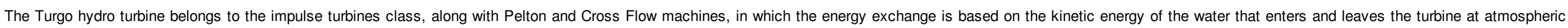

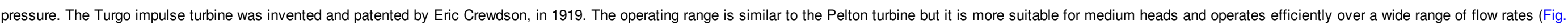
1).

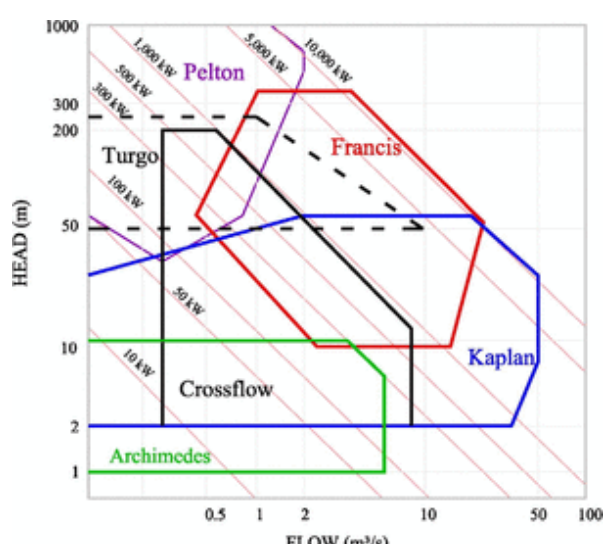




\section{elsevier_APEN_7411}

Fig. 1 Typical application range for various micro- and small-hydro turbines [1].

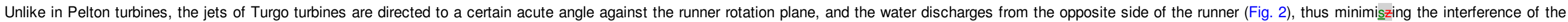

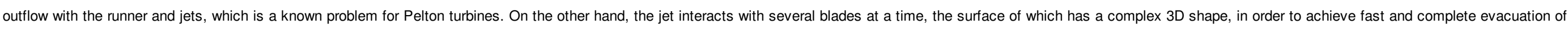
the water and minimise outlet energy (Fig. 3).

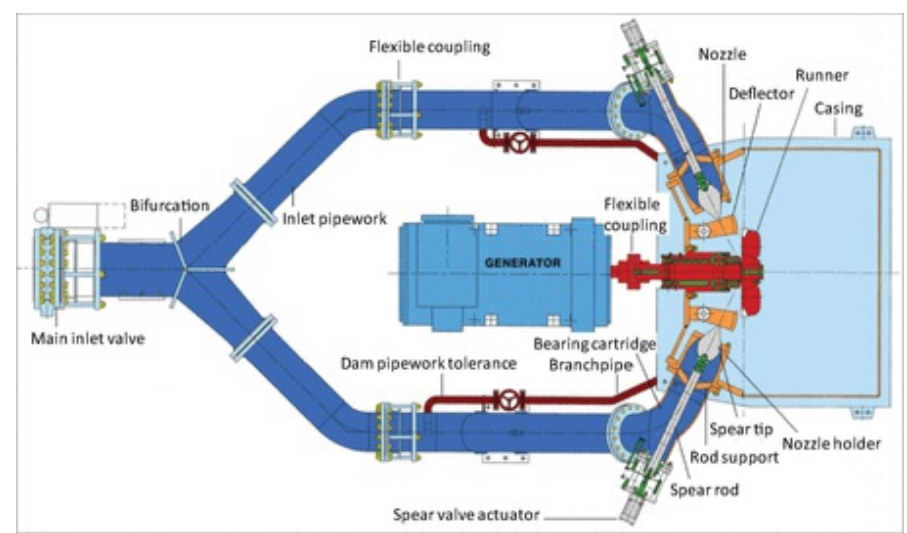

Fig. 2 Typical configuration of a twin jet Turgo turbine (plan view) [2].

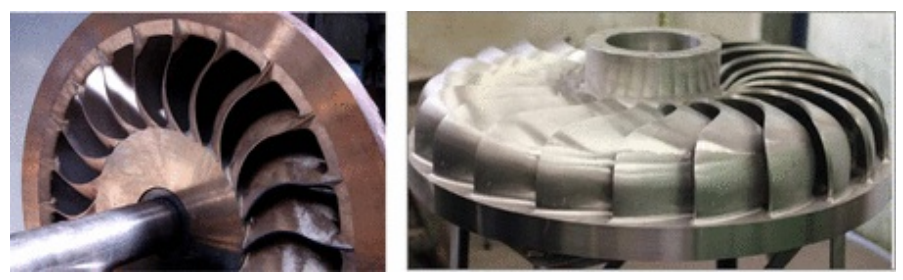

Fig. 3 Design of a typical Turgo runner: front - inlet side (left); back - outlet side (right) [2]

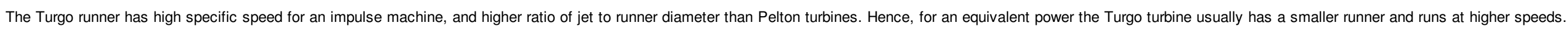
This makes it more feasible to directly connect the turbine shaft to the generator and therefore eliminate the need for transmission systems in medium head environments [2,3].

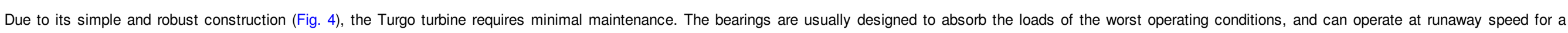
designed period of time, even though the turbine is protected from overspeed conditions using the jet deflectors, which also protect the penstock from surge pressures in a load loss event.

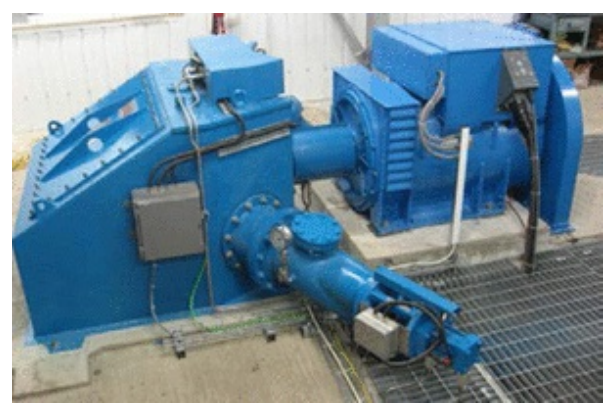

Fig. 4 Typical single-jet Turgo turbine installation, with inlet pipe under the powerhouse floor [2] 


\section{elsevier_APEN_7411}

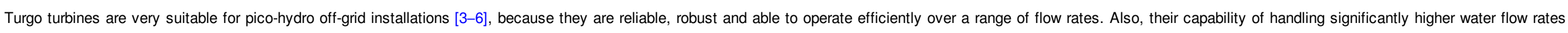

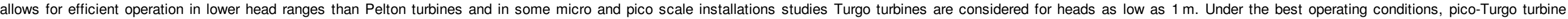
efficiency is observed to be over $80 \%[3]$.

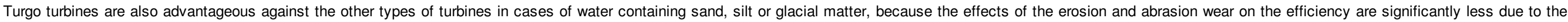
nature of the design: the removal of material is small and evenly distributed across the blade surfaces [2].

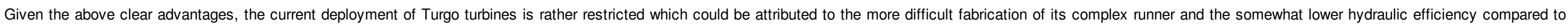

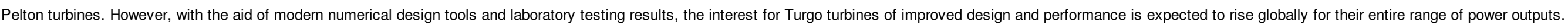

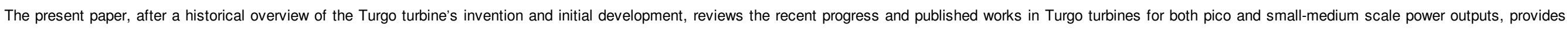
some manufacturing data and concludes with a list of proposals for further development and improvement of these hydro turbines.

\section{Historical data}

\subsection{Invention and early development}

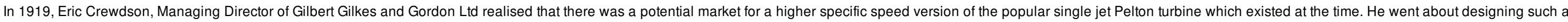

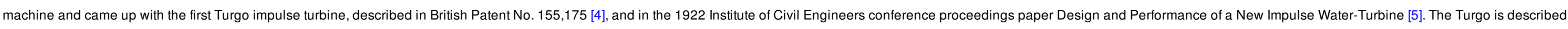
as the incorporation of a Pelton jet to an axial flow turbine runner similar to the Girard turbine (Fig. 5).

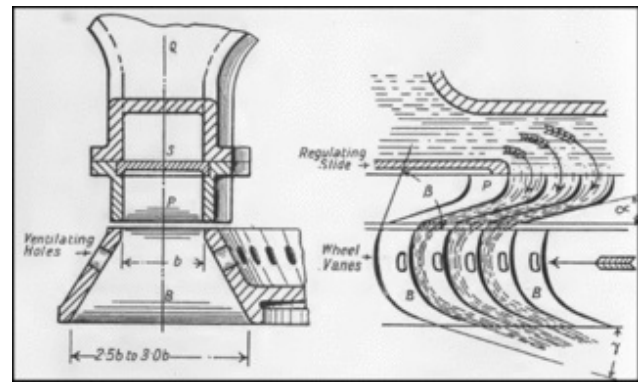

Fig. 5 Axial flow Girard turbine [6].

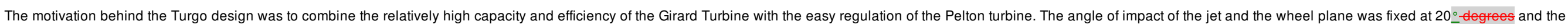
inlet edge peripheral velocity was set to $0.45-0.47$ of the ideal jet velocity [5]

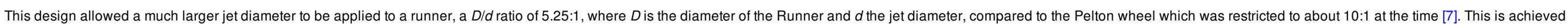
with the jet entering the runner from the front side and expelling water out of the back as shown in Fig. 6. 


\section{elsevier_APEN_7411}

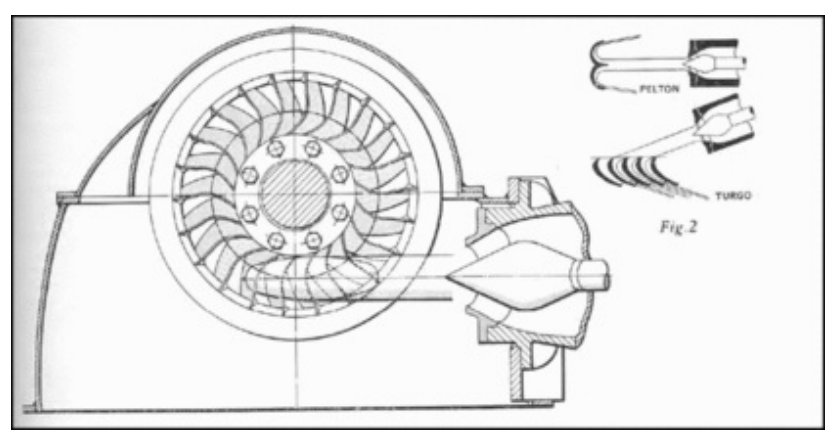

Fig. 6 Pelton and Turgo jet positioning showing inclined nature of Turgo jet [7].

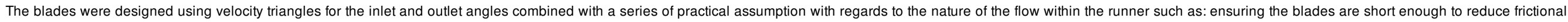

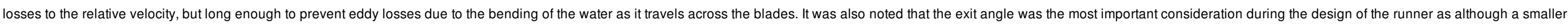

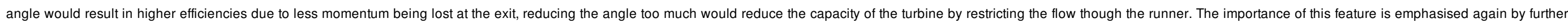

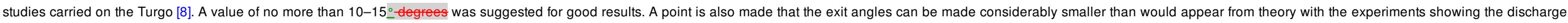
angle to be courser than the exit angle of the blade [5].

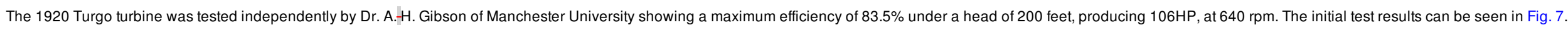

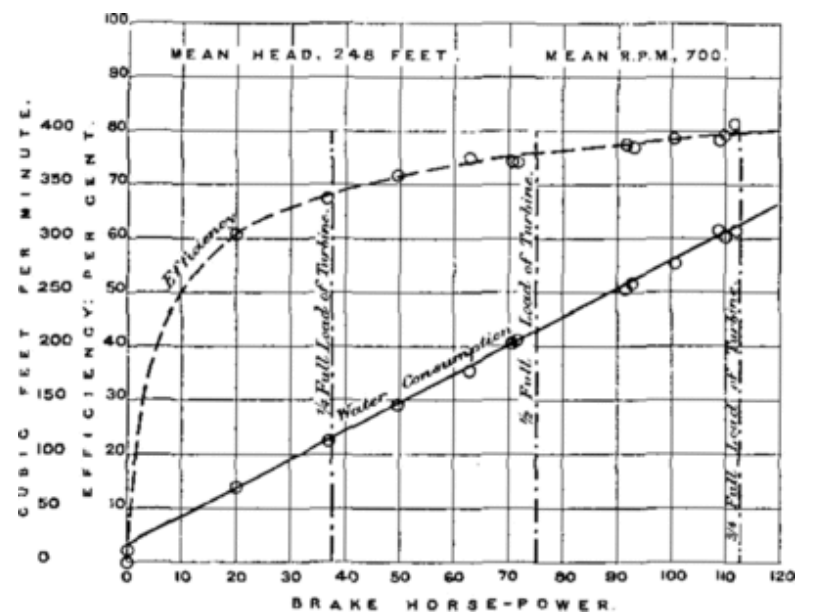

Fig. 7 Test results from 1920 Crewdson Turgo design carried out at Afon Calettwr [5]

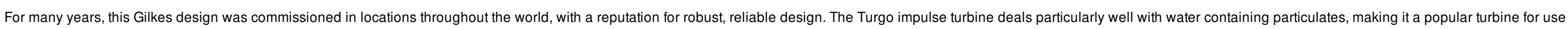
in mining districts [7].

\subsection{Further Đevelopmentdevelopment}

\subsubsection{Gilkes Researeh research and Developmentdevelopment}

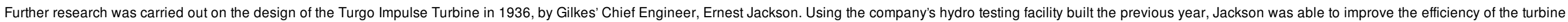
and reduce the D/d ratio to 4.5:1 [7], by moving the path of the jet so that it struck the runner ahead of the centreline as shown in Fig. 8. The details of this design can be found in British Patent Number 468,557 [9]. 


\section{elsevier_APEN 7411}

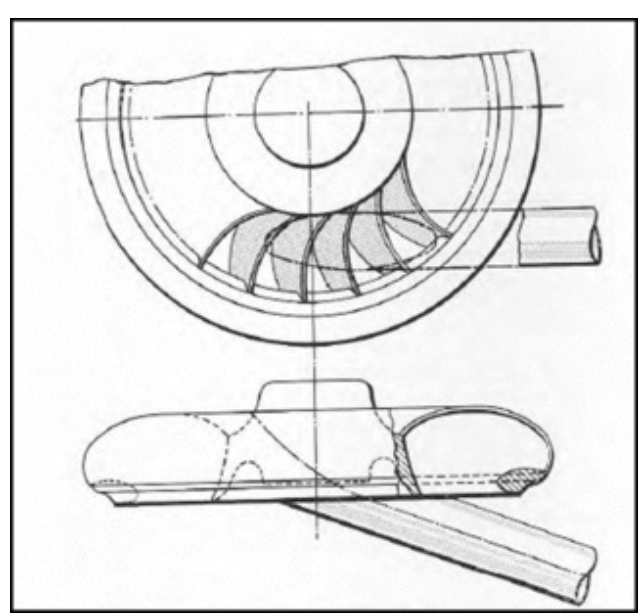

Fig. 8 The 1936 modified Turgo design, showing the shifted point of impact between the jet and the runner.

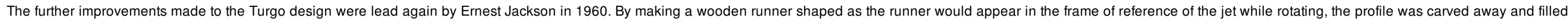

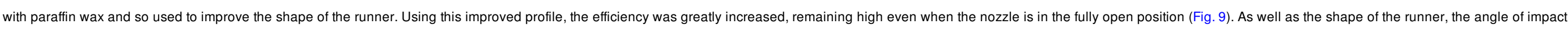

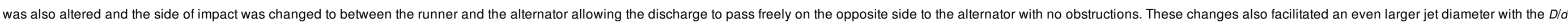
ratio falling to 3.75:1 For the complete redesign of the runner, the British Patent Number 938938.967 [10] was granted on 2nd May 1961 [7].

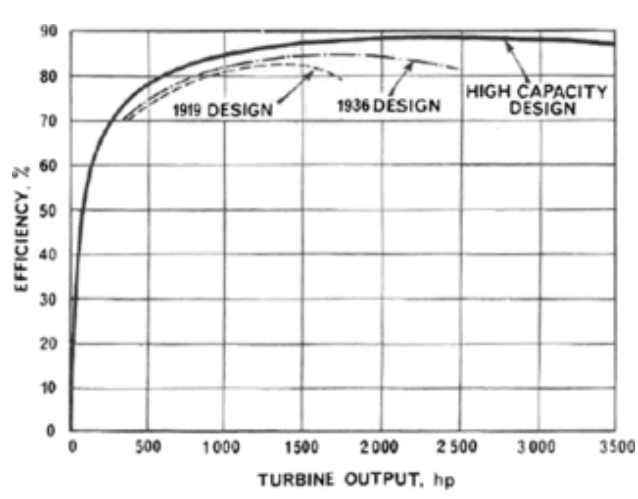

Fig. 9 Efficiency and output for a 24 in. mean diameter Turgo under a head of $750 \mathrm{ft}[7]$.

\subsubsection{Independent research and development}

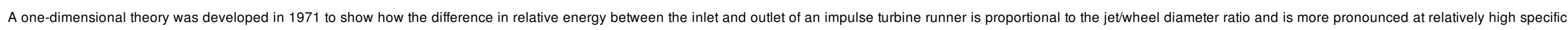
speeds where the fall in efficiency due to mixing is greater [11].

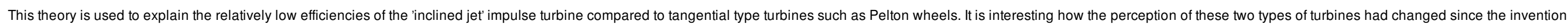

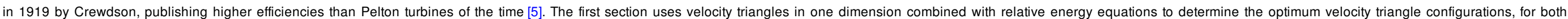

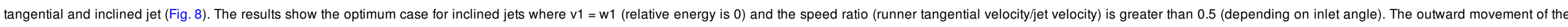

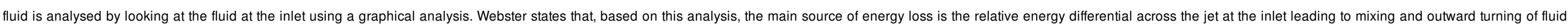
across blade [11]. 


\section{elsevier_APEN_7411}

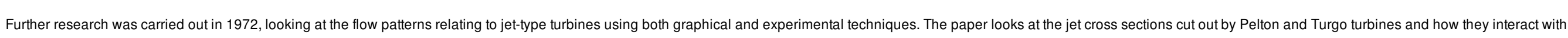
various runners. A dimensional analysis is carried out first followed by experimental measurements of flow patterns relating to different rectangular and semi-circular cross sections [8].

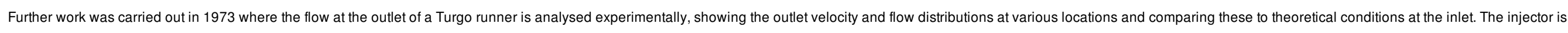

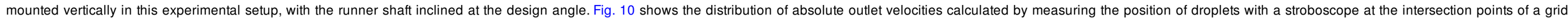

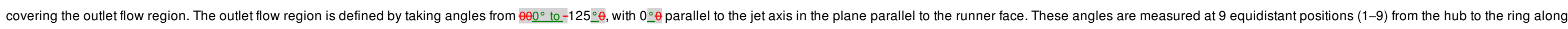
the curved rim of the bucket. This three dimensional region is plotted in two dimensions by developing the curved rim of the bucket into a straight line [12].

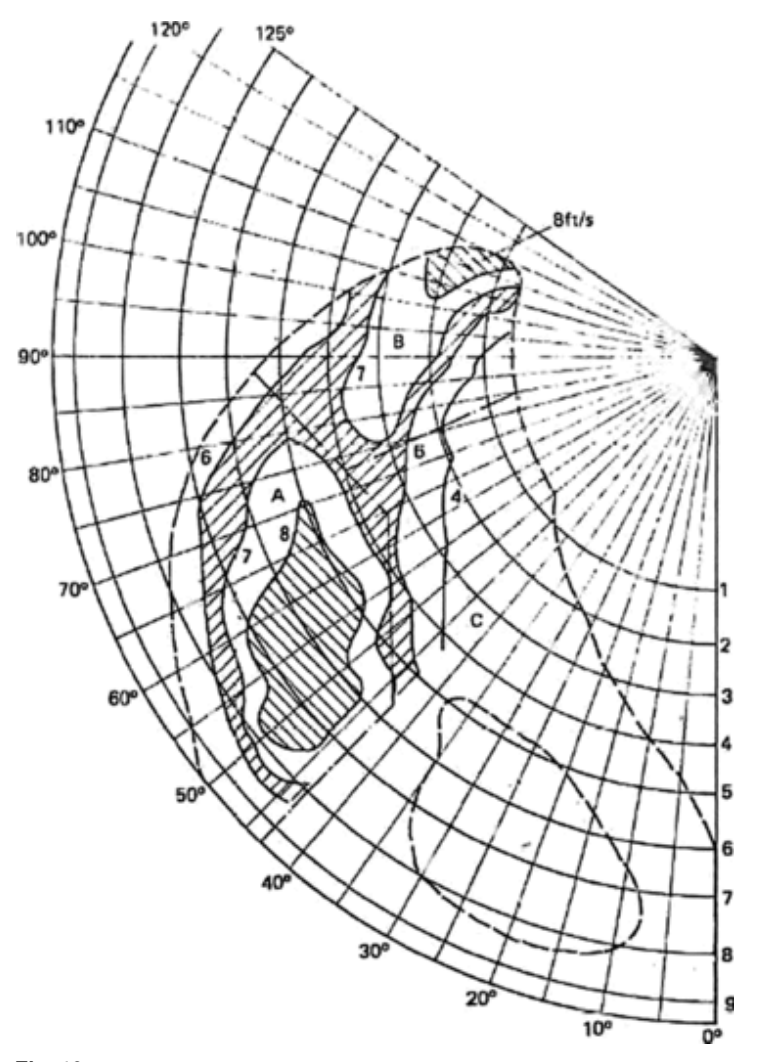

Fig. 10 Experimental absolute velocities at the outlet of the Turgo runner in feet/s [12].

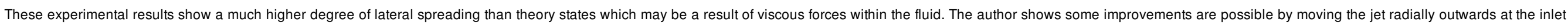
and carried out tests showing a $4 \%$ increase in efficiency [12].

\section{Recent development and applications}

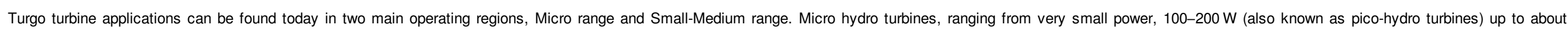

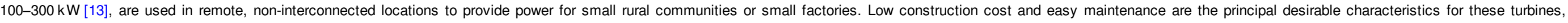

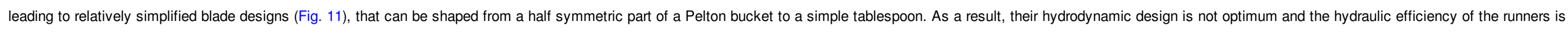
relatively low. 


\section{elsevier_APEN_7411}

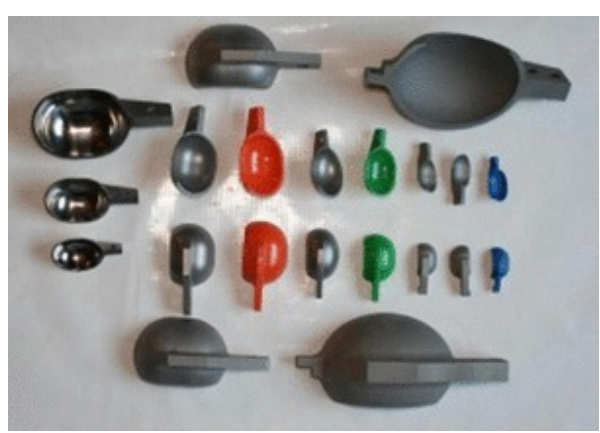

Fig. 11 Turgo turbine blades for micro hydropower [14].

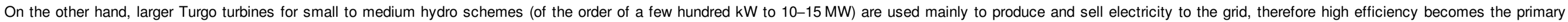

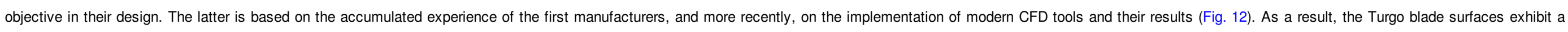
more complex 3D shape with these runner designs (Fig. 13).

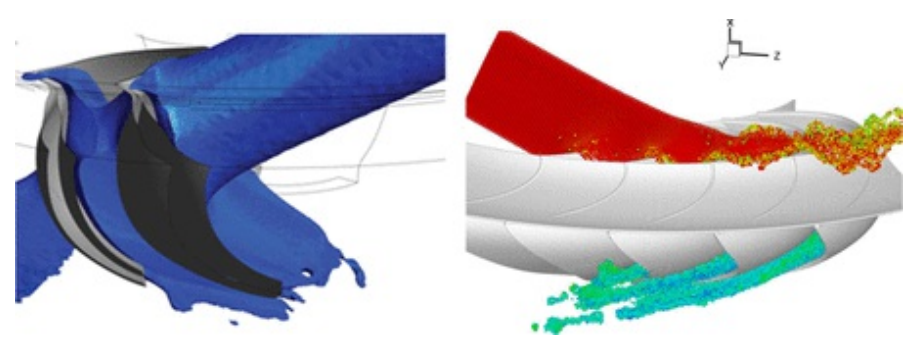

Fig. 12 Flow simulation in Turgo runners using CFD tools: left [2], and right [15]
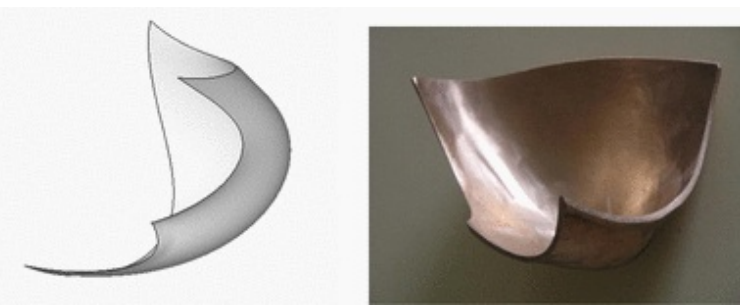

Fig. 13 Indicative blades of a model Turgo turbine with optimiszzed shape [15]

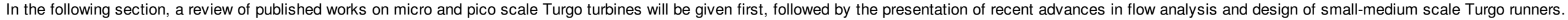

\subsection{Pico and micro-Turgo turbines}

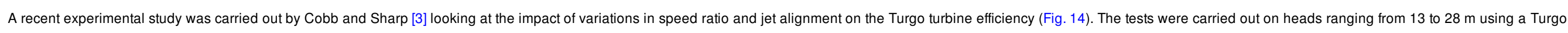

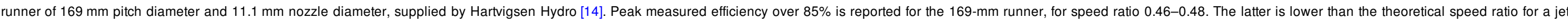

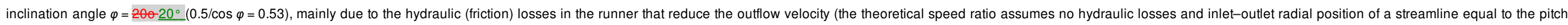

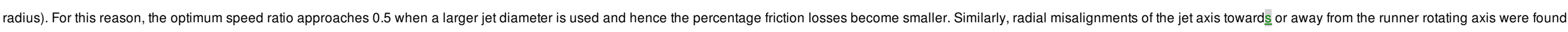

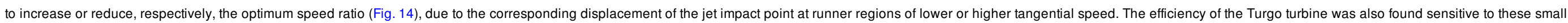
radial misalignments of the jet, and hence visual adjustments cannot be adequate for achieving the highest turbine efficiency. 


\section{elsevier_APEN_7411}

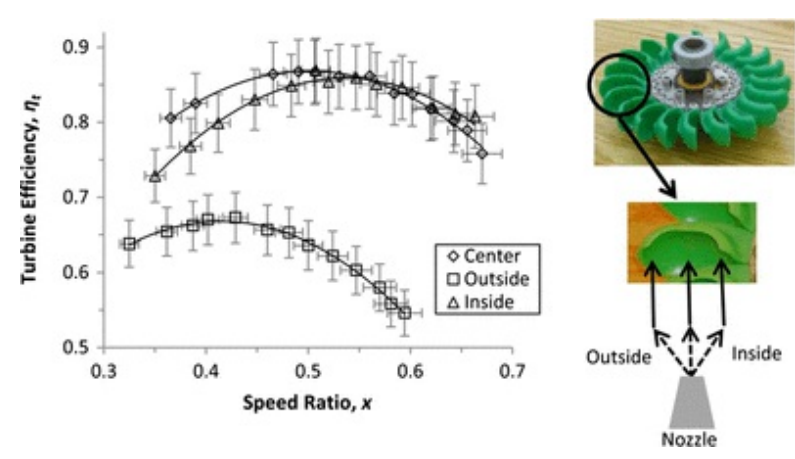

Fig. 14 Turgo turbine efficiency vs. speed ratio for three radial jet positions [3].

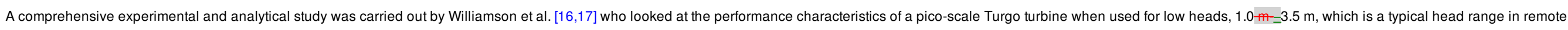

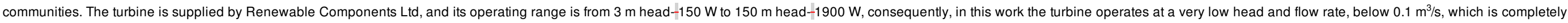
outside of its typical application domain (Fig. 1).

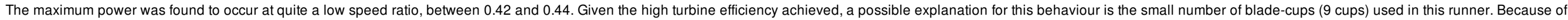

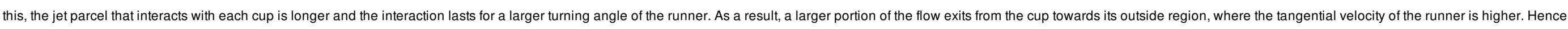
the rotational speed of the runner should be reduced to minimiszze the kinetic energy of the outflow.

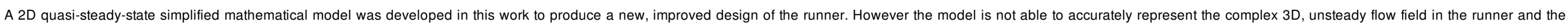

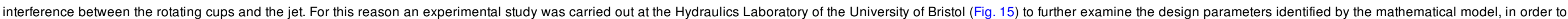
improve the turbine efficiency and overall performance.

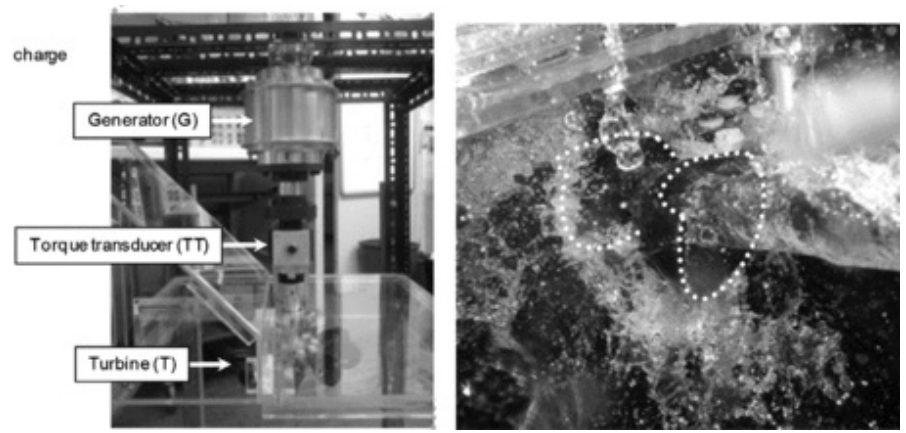

Fig. 15 Turgo turbine laboratory tests : Model turbine set up (left), and jet-runner interaction (right - cups are marked by dotted lines) [17]

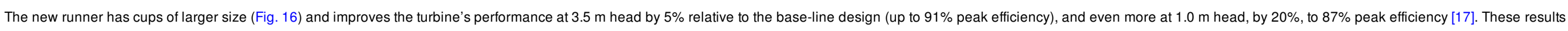

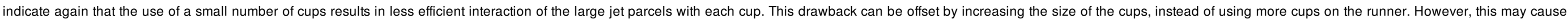
higher windage losses to arise from the rotating runner. 


\section{elsevier_APEN_7411}

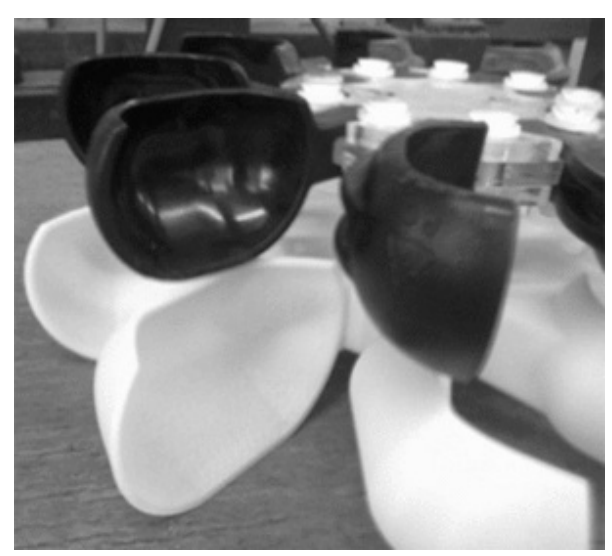

Fig. 16 Comparison of the commercially available (black) and the redesigned (white) Turgo runner [17].

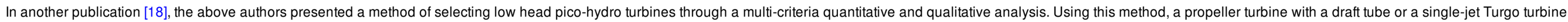

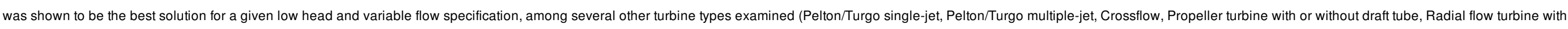
or without draft tube, Archimedes screw, Overshot water wheel, Breastshot water wheel and Undershot water wheel.)

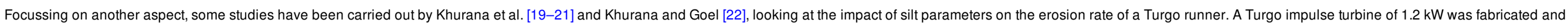

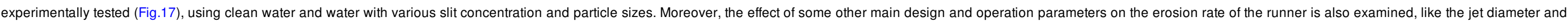
velocity, the nozzle angle, and the operation time [19-21].
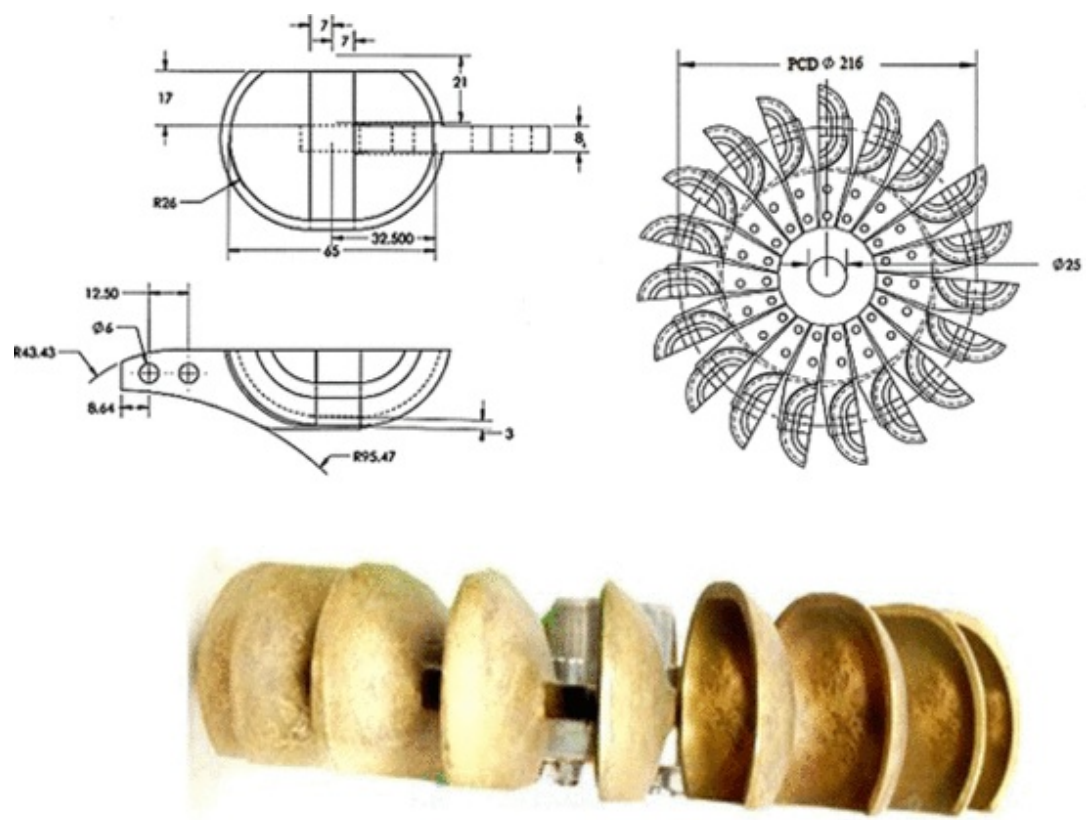

Fig. 17 Turgo runner picture and dimensions in the experiments of Khurana et al. [19,21].

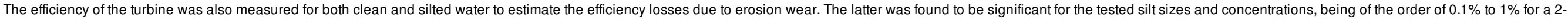




\section{elsevier_APEN_7411}

h operation of the turbine [19].

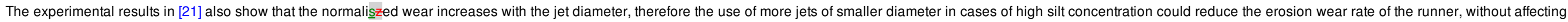
the turbine output.

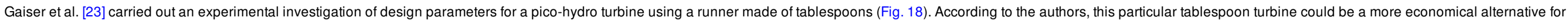
off-grid villages than hydroelectric turbines, because it does not require casting and pattern-made moullds and the cost is considerably lower than imported commercial hydro turbines.
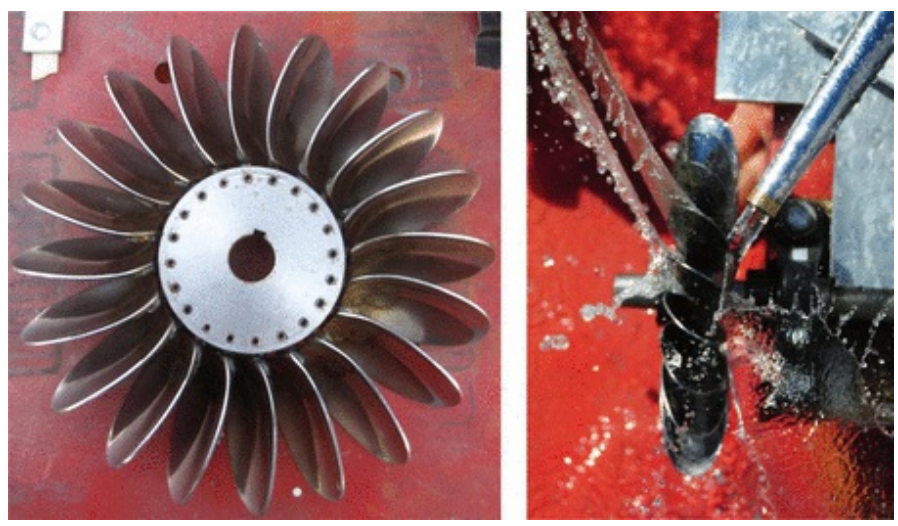

Fig. 18 Turgo runner made of tablespoons (left) and its operation (right) [23].

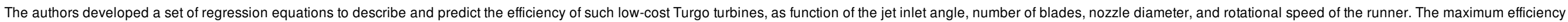
of this particular runner [23] was low, tested at about 63\%, and this was attributed to the relatively large skin friction and eddy formation in the runner cups, the shape of which is very shallow compared to typical Turgo blades.

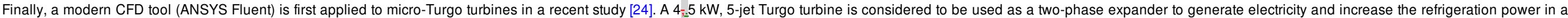
refrigeration system (Fig. 19).

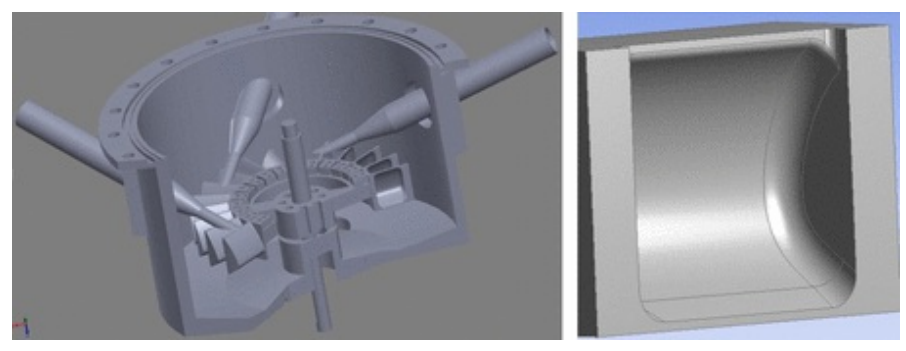

Fig. 19 Section view of the turbine enclosure (left), and bucket shape (right) [24].

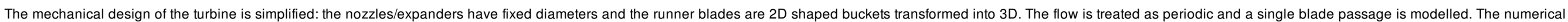

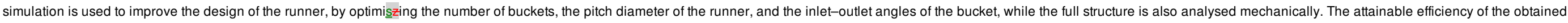
design was computed at $40 \%$, which, although quite low due to the simplistic hydrodynamic shape of the buckets, would increase the total refrigeration power of the considered cycle by $0.8 \%$ [24].

\subsection{Small-medium scale Turgo turbines}

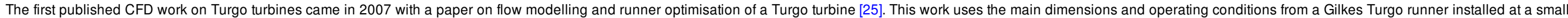

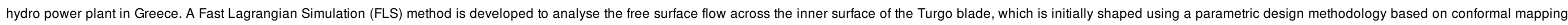




\section{elsevier APEN 7411}

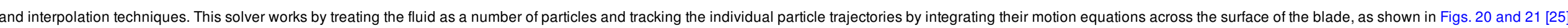
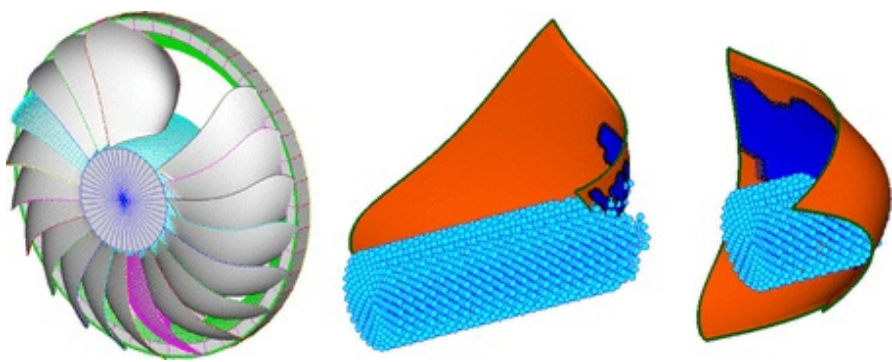

Fig. 20 Parametric design of Turgo runner (left) and flow modelling snapshots (right), [25]

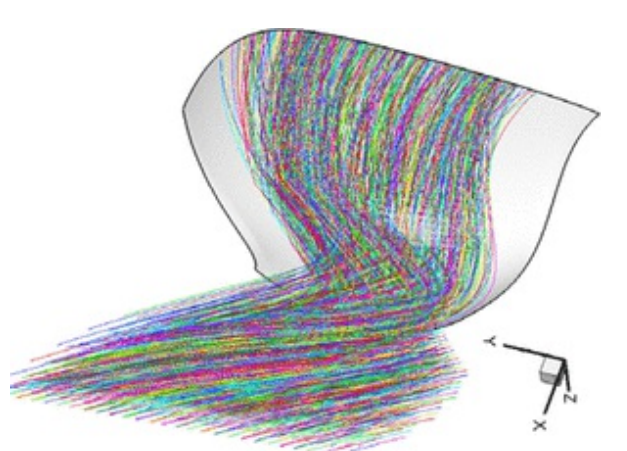

Fig. 21 Indicative particle trajectories generated by the Lagrangian solver [25].

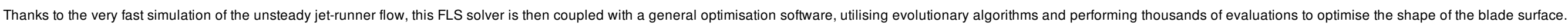
The results show a $6 \%$ increase in efficiency between the standard and the optimised runner, with a maximum efficiency of $85 \%$ [25]

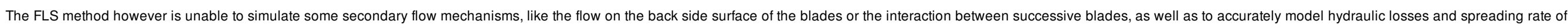

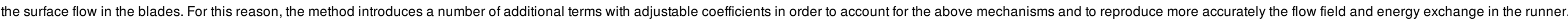

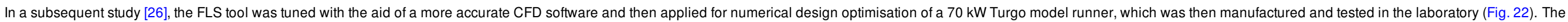

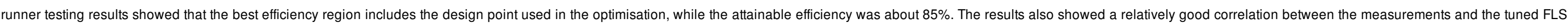
model outputs (Fig. 23).

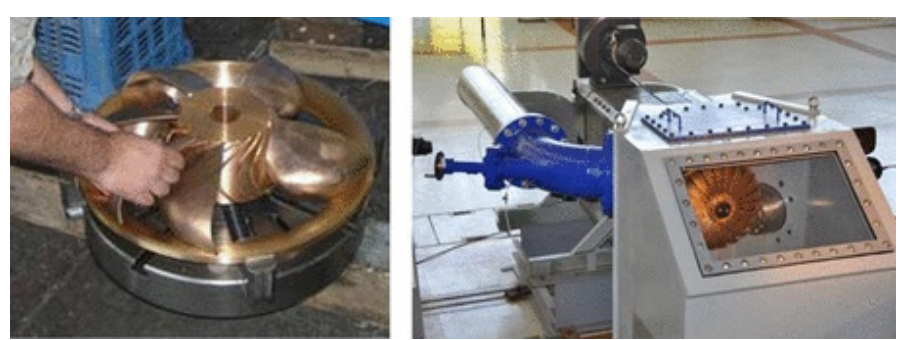

Fig. 22 Manufacture of the model Turgo runner (left) and installation in the Lab (right), [26]. 


\section{elsevier_APEN_7411}

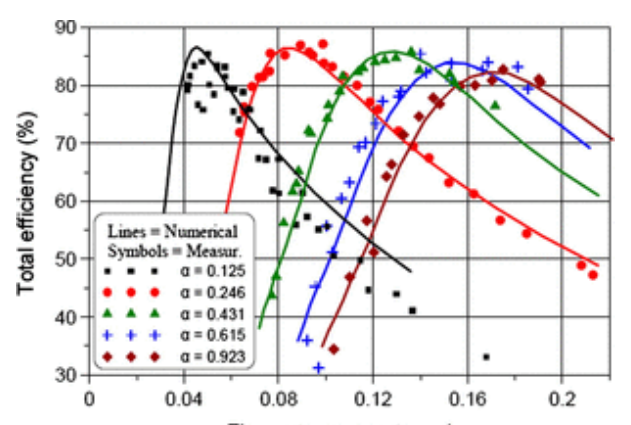

Flow rate parameter, $\Phi$

Fig. 23 Comparison between experimental and FLS numerical model results for various spear valve openings, $\alpha$ [26].

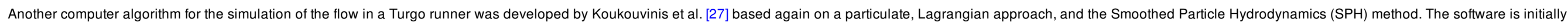

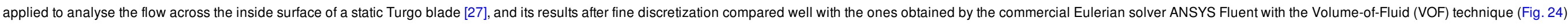

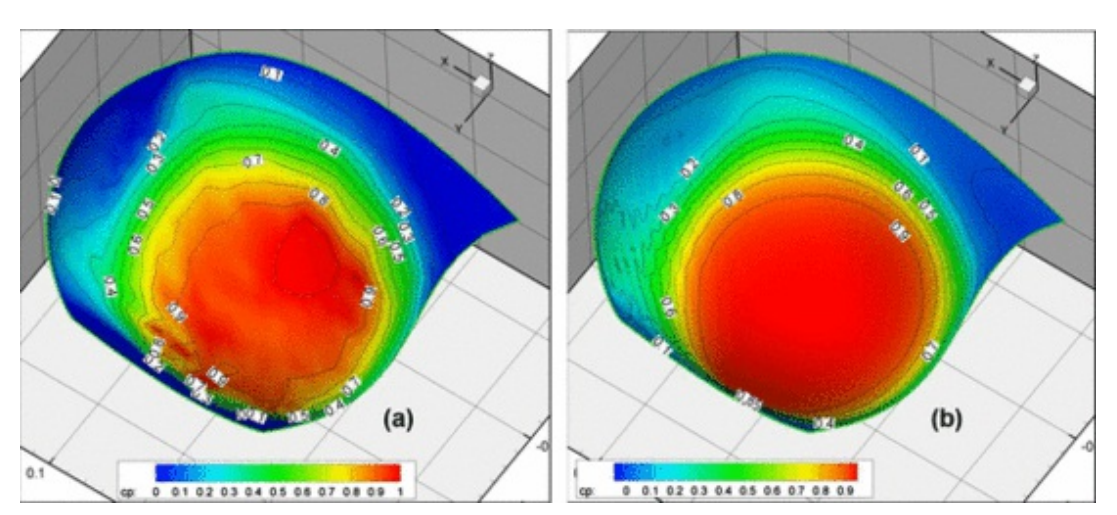

Fig. 24 Pressure coefficient distribution on the inner surface of a static blade obtained by SPH (left) and Fluent-VOF (right) [27].

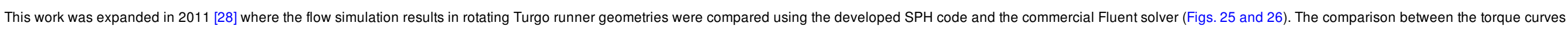

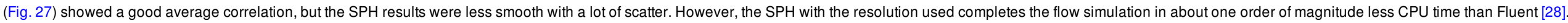

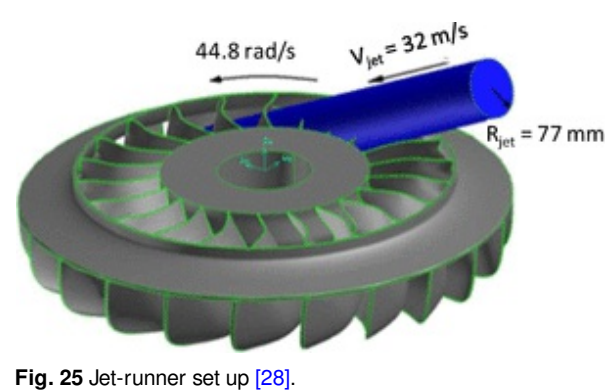

Fig. 25 Jet-runner set up [28]. 


\section{elsevier_APEN_7411}

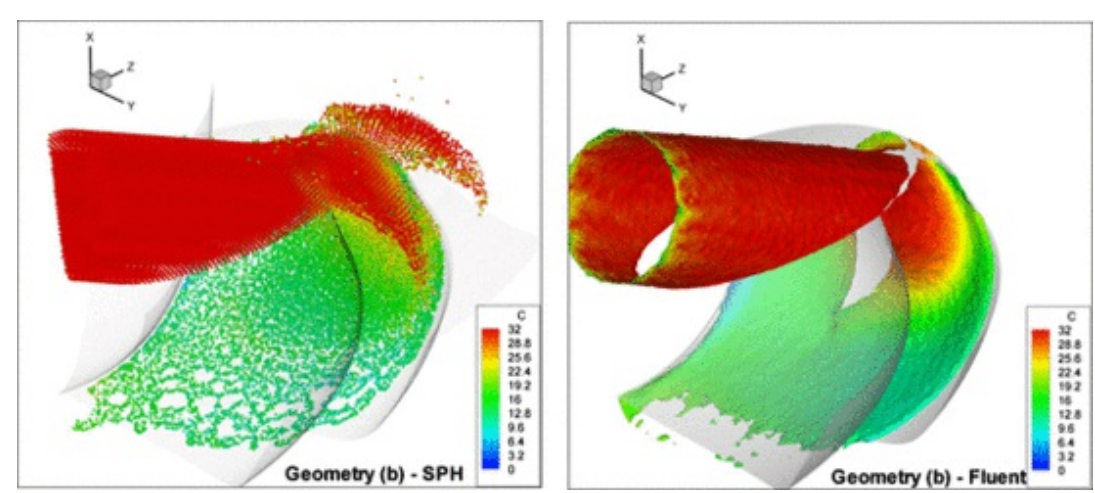

Fig. 26 Flow comparison between SPH and ANSYS Fluent results [28].

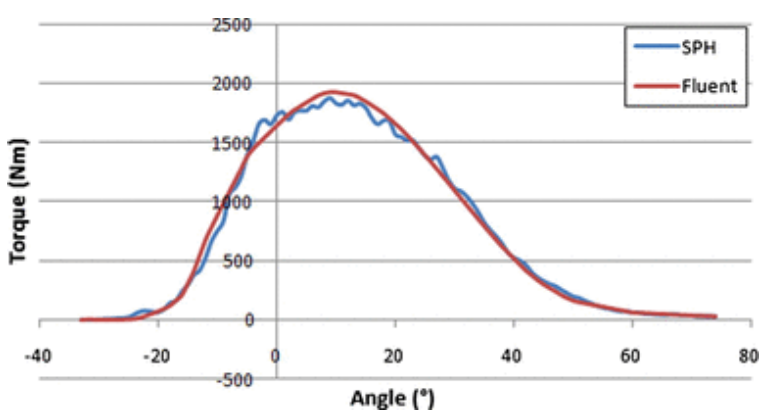

Fig. 27 Comparison of SPH and ANSYS Fluent results for the Torque curve developed on a blade, zero angle refers to vertical blade position [28].

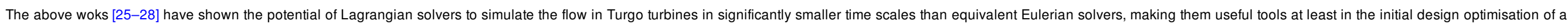
blade surface, with the ability to analyse many design permutations.

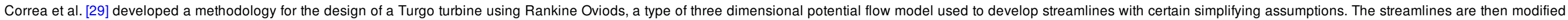

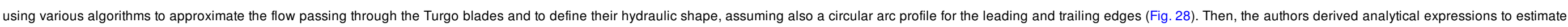

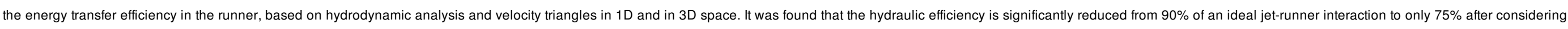

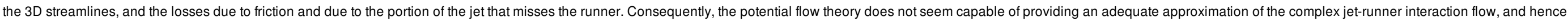
it cannot be used for the design of runner blades in Turgo turbines.

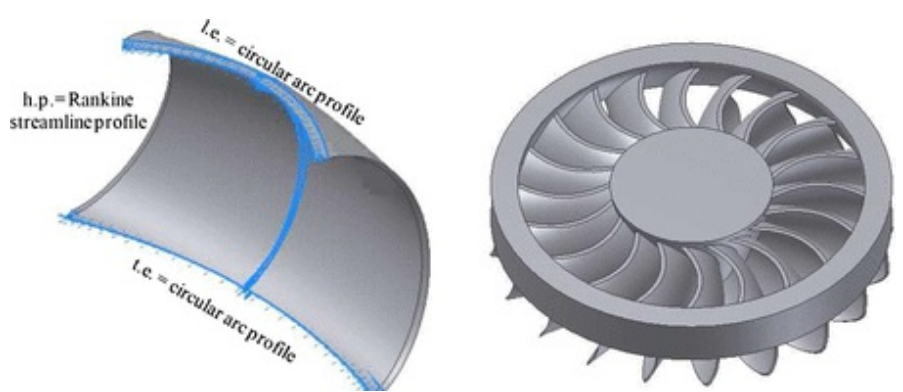

Fig. 28 Turgo blade and runner created by the analytic approximation method of [29]. 


\section{elsevier_APEN_7411}

with 20 blades as well as the casing, with just over 2 million elements, corresponding to roughly $100 \mathrm{k}$ elements per blade passage.

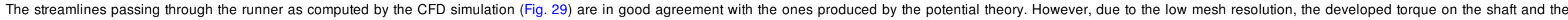

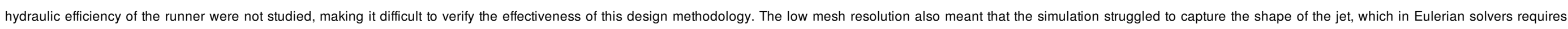

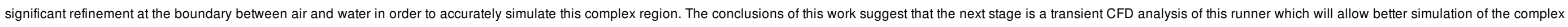
multi-phase flow, with more accurate calculations of torque and efficiency.
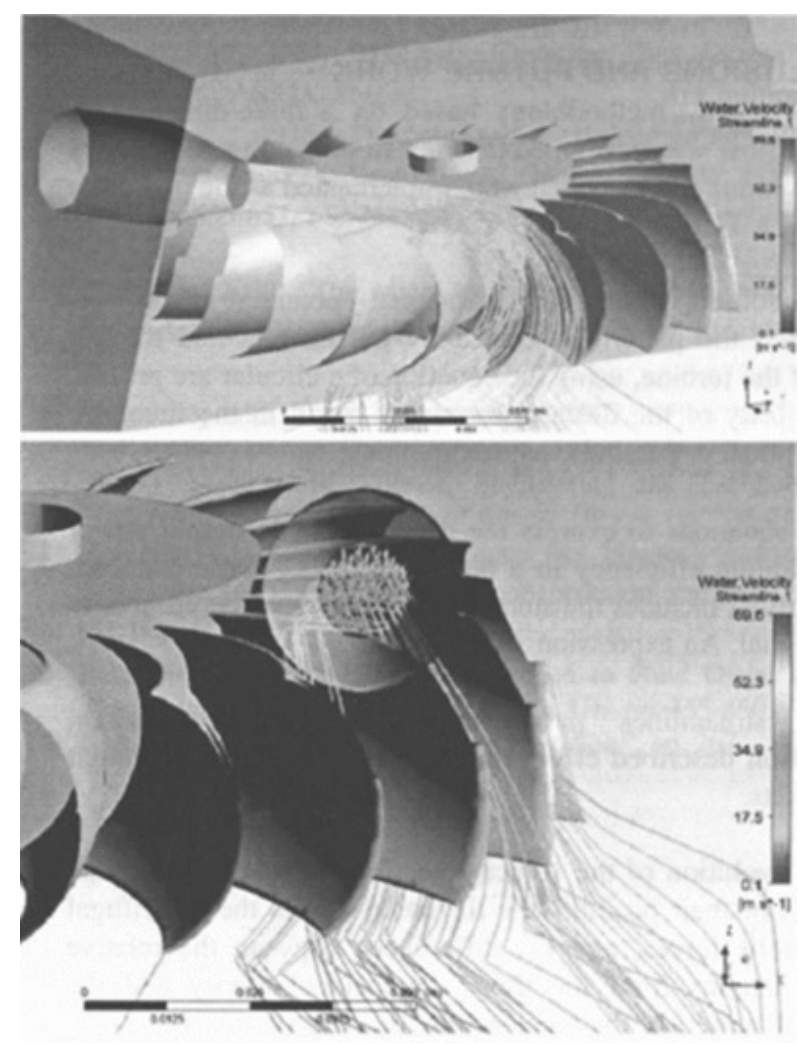

Fig. 29 Flow streamlines in the Turgo runner as computed by Correa et al. [30].

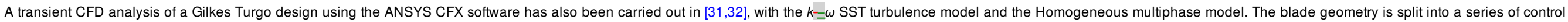
curves (Fig. 30), which can be used to adjust the shape of the blades and runner, based on flow visualiszation or using systematic numerical simulation procedures.
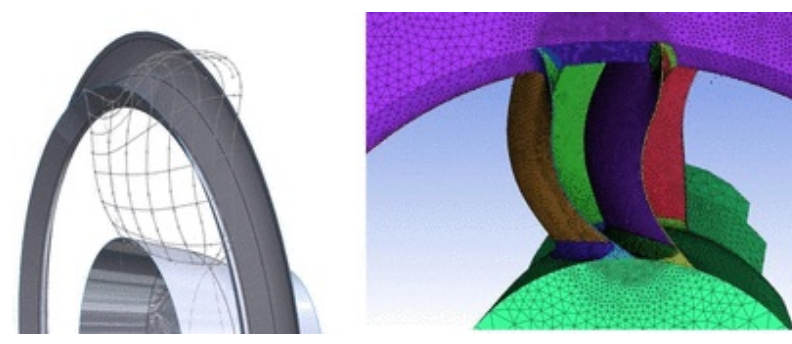

Surtace

Fig. 30 Parametric design of blade shape and surface mesh structure $[31,32]$ 


\section{elsevier_APEN_7411}

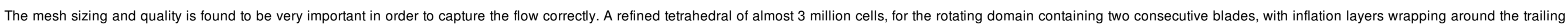
edge (Fig. 31) is found to produce results of satisfactory accuracy ( $\pm 1 \%$ in efficiency, [32]).
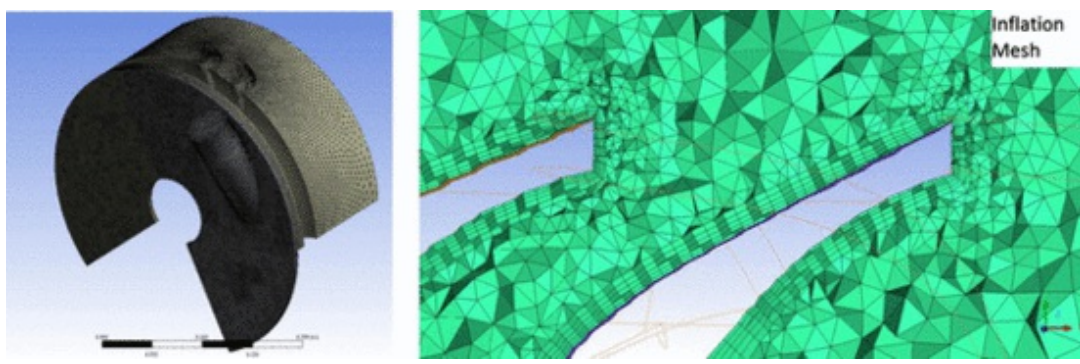

Fig. 31 Computational domain and mesh (left), and detailed view at the blades trailing edge region [31,32]

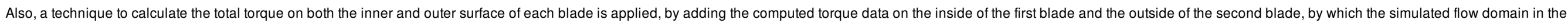
runner can be restricted to the region between two successive blades [32]. The complete CFD simulation provides comprehensive pictures and important details of the complex flow field during the jet-runner interaction (Fig. 32).
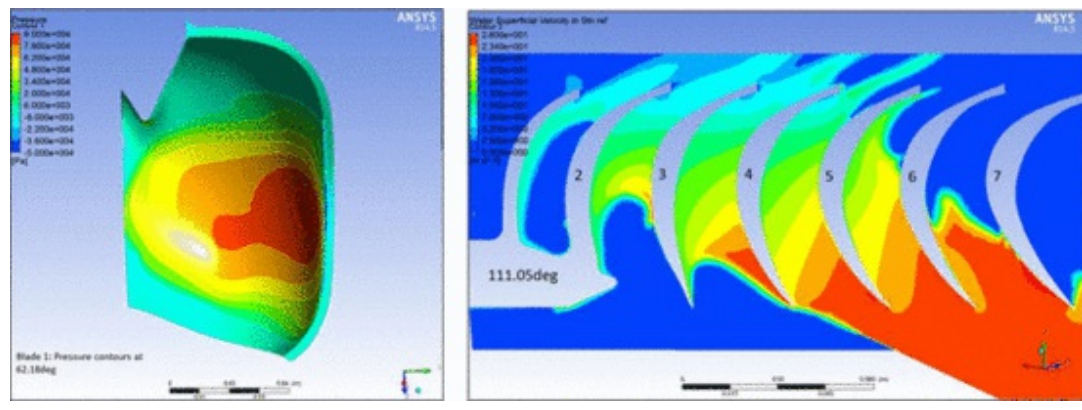

Fig. 32 Indicative CFD results for the flow in a Turgo turbine runner: Pressure profiles (left); velocity profiles (right) [31].

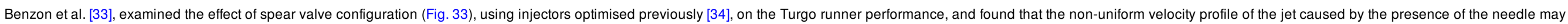
be responsible for about $0.8 \%$ more energy losses in the runner, compared to an ideal uniform jet profile [33].

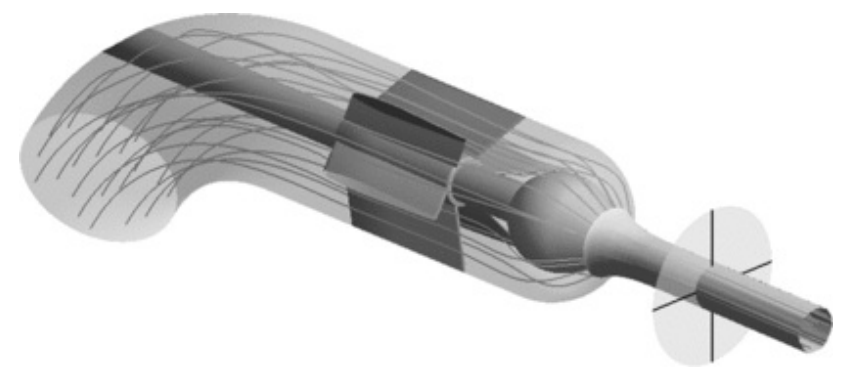

Fig. 33 Typical configuration of a Turgo turbine injector [33].

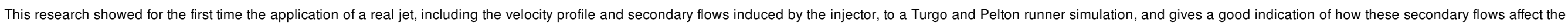
runner performance. Although this work validates the ability of Eulerian CFD solvers to capture these complex flow phenomena, experimental studies would be required in order to verify the accuracy of these simulations.

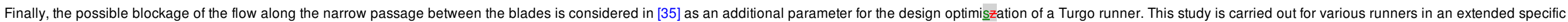




\section{elsevier_APEN_7411}

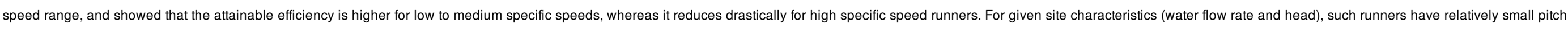

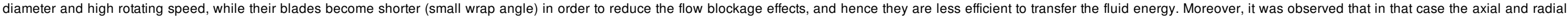

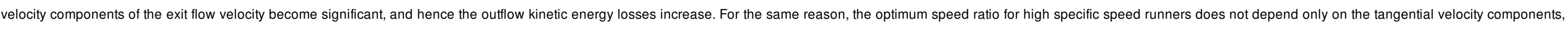
and it may take values even above the theoretical ones (almost 0.6, compared to theoretical 0.55 for a jet inclination angle of $25_{-}^{\circ}$ deg [35]).

\subsection{Turgo turbine manufacturers}

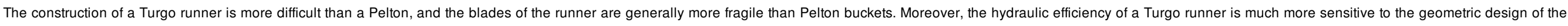
blades, which have a complex 3D shape. Hence, a non-optimum runner design may attain considerably lower efficiencies than a corresponding conventional Pelton runner.

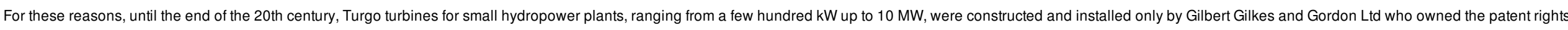

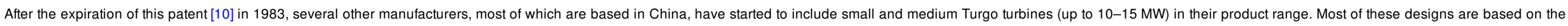

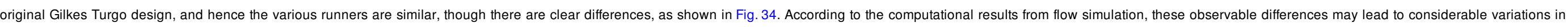

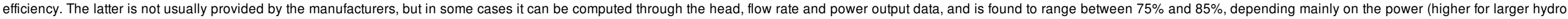
turbines), but also on the specific manufacturer. Most of these manufacturers do not implement CFD in their runner design. Therefore, there is a significant margin for further improvements in performance and efficiency of their products. 
elsevier_APEN_7411

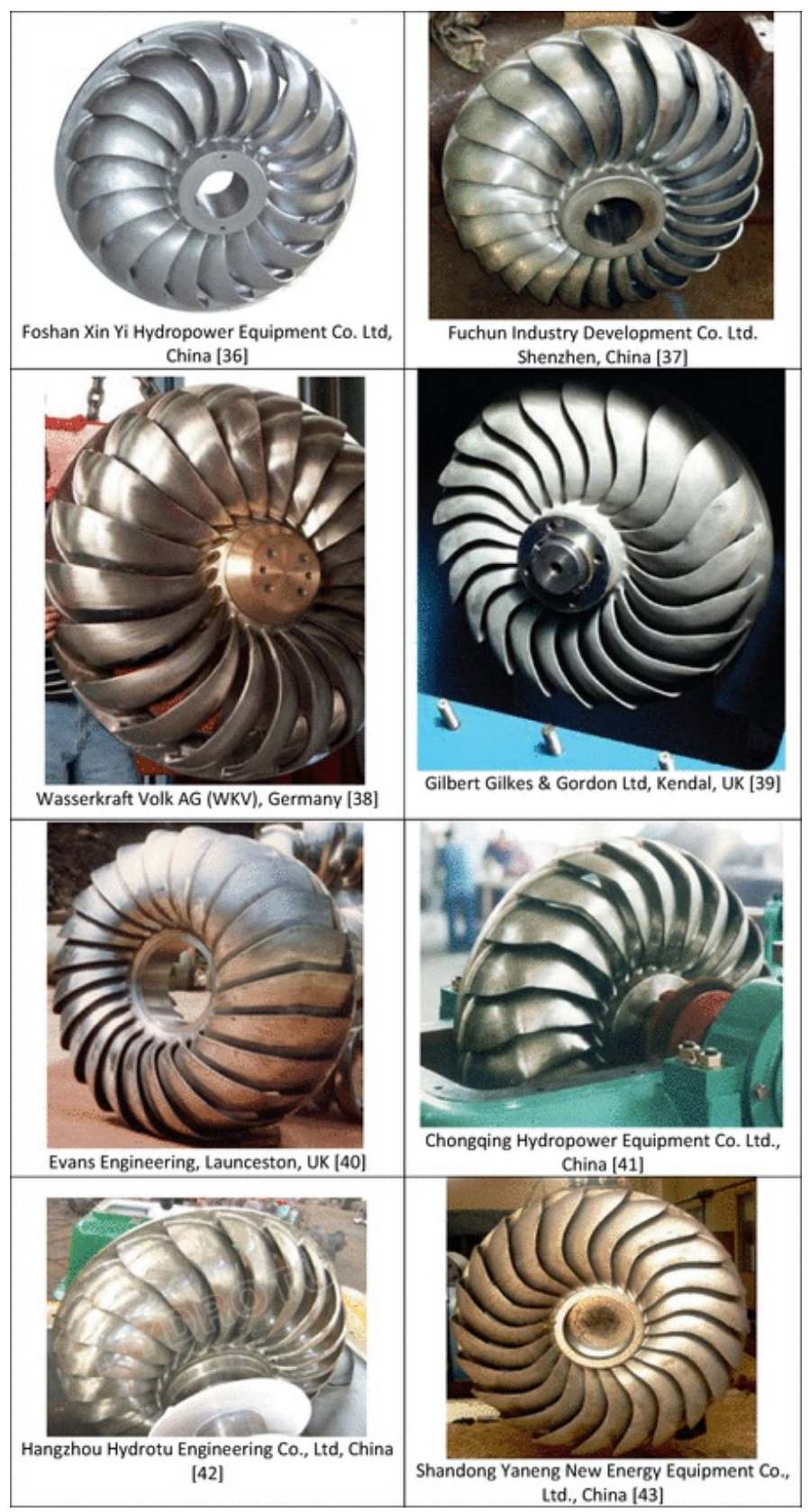




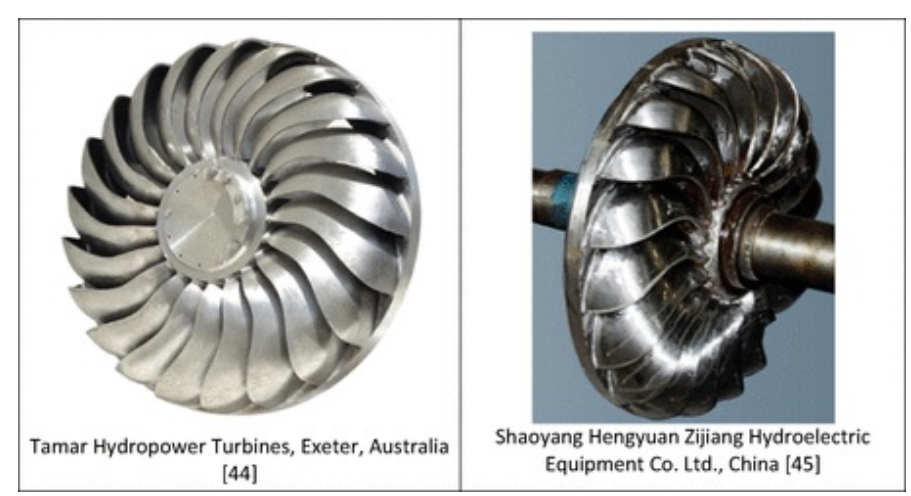

Fig. 34 Selection of small-medium scale Turgo turbine manufacturers [36-45].

\section{Open issues for further research and development}

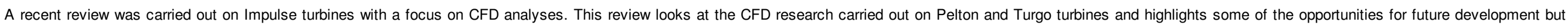
focuses on the development of CFD in the analysis and optimisation of these runners [46].

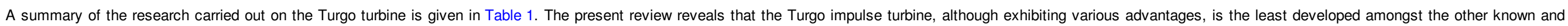

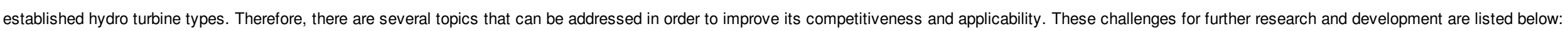

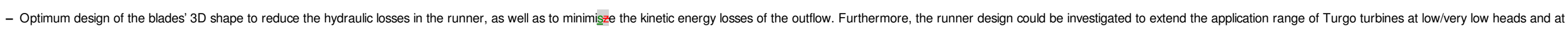
high heads, with competitive performance and efficiency.

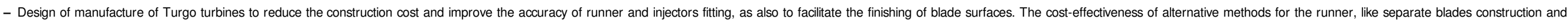
assembly or machining, may be also considered.

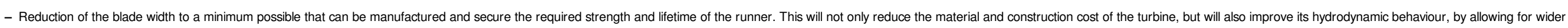
flow passage between the blades and for further reduction of the outflow energy losses.

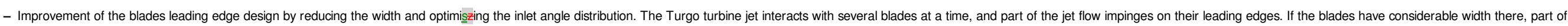
the flow impacts at high angles on the edges causing disturbances in the flow entering the runner and energy losses.

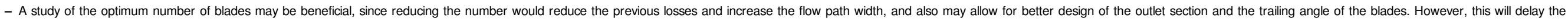
evacuation of the blades and may causes higher hydraulic losses.

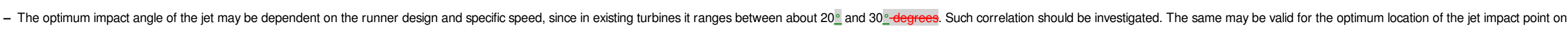
the inlet plane of the runner.

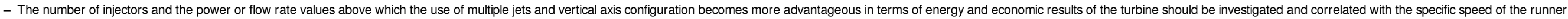
or with other flow parameters.

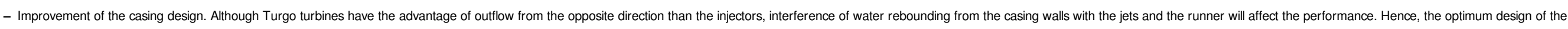
casing is an important issue, in order to minimisze such interference and at the same time to reduce as much as possible the volume and cost of the casing.

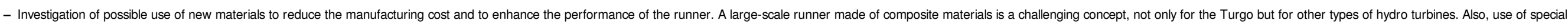
alloys or coatings to reduce erosion wear can prolong the lifetime of the runner in the case of higher sitt concentrations in the water.

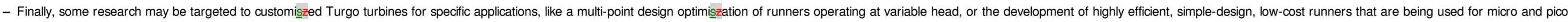




\section{elsevier_APEN_7411}

hydropower production in developing countries and remote isolated regions.

Table 1 Summary of research carried out on Turgo turbines by research area.

\begin{tabular}{|c|c|c|c|c|c|c|c|c|c|}
\hline \multirow{3}{*}{ Turbine Scale } & \multirow{3}{*}{$\begin{array}{c}\text { Research } \\
\text { Area }\end{array}$} & \multicolumn{4}{|c|}{ Nature of research (number of publications) } & \multirow{3}{*}{$\begin{array}{l}\text { Scope for further } \\
\text { development }\end{array}$} & \multirow{3}{*}{ References } & \multirow{3}{*}{$\begin{array}{l}\text { Most Recent } \\
\text { Publication }\end{array}$} & \multirow{3}{*}{ Comments } \\
\hline & & \multirow{2}{*}{ Theoretical } & \multicolumn{2}{|c|}{ Numerical } & \multirow[t]{2}{*}{ Experimental } & & & & \\
\hline & & & Eulerian & Lagrangian & & & & & \\
\hline \multirow[t]{3}{*}{ Pico hydro (100 W-100 kW) } & $\begin{array}{l}\text { Runner } \\
\text { design }\end{array}$ & 2 & 1 & & 2 & High & {$[15,23,24]$} & 2016 & $\begin{array}{l}\text { - Experimental optimisations show good efficiencies } \\
\text { - More research can be done using CFD }\end{array}$ \\
\hline & $\begin{array}{l}\text { Injector } \\
\text { design }\end{array}$ & 1 & & & 3 & Medium & [19-22] & 2014 & $\begin{array}{l}\text { - Little has been done with optimisations of the injectors for } \\
\text { improved hydraulic performance }\end{array}$ \\
\hline & Operation & 3 & 1 & & 3 & High & {$[1,3,16,18,23,24]$} & 2016 & $\begin{array}{l}\text { - Some experimental studies have been carried out over a limited } \\
\text { operating range } \\
\text { - Very little CFD available }\end{array}$ \\
\hline \multirow[t]{3}{*}{$\begin{array}{l}\text { Small-medium hydro } \\
(100 \mathrm{~kW}-10 \mathrm{MW})\end{array}$} & $\begin{array}{l}\text { Runner } \\
\text { design }\end{array}$ & 6 & 5 & 5 & 3 & High & {$[2,4,5,8-11,14,25-32,35]$} & 2014 & $\begin{array}{l}\text { - Several theoretical studies are available } \\
\text { - Some work has been done using CFD but there is scope for more } \\
\text { accurate simulations and further optimisations }\end{array}$ \\
\hline & $\begin{array}{l}\text { Injector } \\
\text { design }\end{array}$ & 1 & 2 & & & Medium & {$[33,34]$} & 2015 & $\begin{array}{l}\text { - There are some recent injector studies which use 'real' jet profiles } \\
\text { coupled with runner CFD } \\
\text { - More general research looking at impulse turbine injectors not } \\
\text { covered in this review }{ }^{\mathrm{a}}\end{array}$ \\
\hline & Operation & 2 & 3 & 2 & 1 & High & {$[7,8,10,11,25,28,31,32]$} & 2014 & $\begin{array}{l}\text { - Limited experimental studies available } \\
\text { - Several CFD studies using Lagrangian solvers } \\
\text { - Little CFD using Eulerian solvers }\end{array}$ \\
\hline
\end{tabular}

a A more detailed review of injectors for impulse turbines is provided in [46].

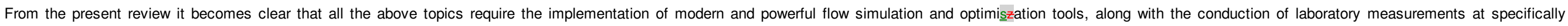

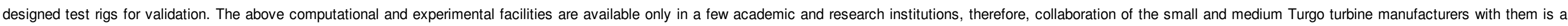
prerequisite for further development of Turgo turbines.

\section{Conclusions}

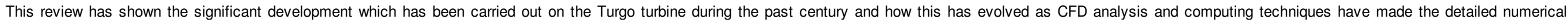




\section{elsevier_APEN_7411}

calculation of the associated flows possible.

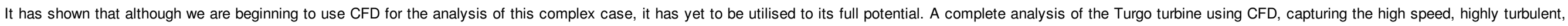

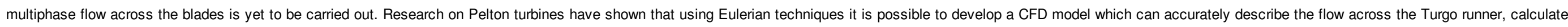
the torque developed and the efficiency, and capture small changes in the design in a reasonable timescale.

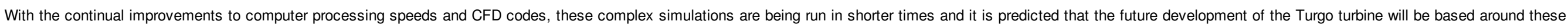
numerical analyses.

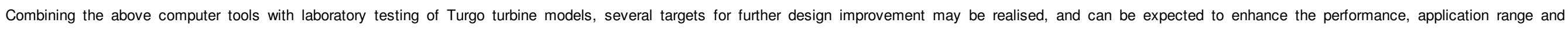
competitiveness of Turgo turbines.

\section{References}

[1]

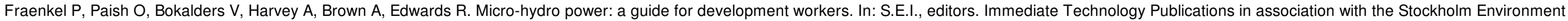
Institute, London; 1991.

[2]

Gilkes. Gilkes Turgo impulse hydro turbine; 2015. <http://www.gilkes.com/user_uploads/turgo\%20paper2.pdf> [accessed 01.04.14].

[3]

B.R. Cobb and K.V. Sharp, Impulse (Turgo and Pelton) turbine performance characteristics and their impact on pico-hydro installations, Renewable Energy 50, 2013, 959-964.

[4]

Gilbert Gilkes \& Gordon Ltd. Improvements in water turbines. United Kingdom Patent; 1920.

[5]

Crewdson E. Design and performance of a new impulse water-turbine. In: Minutes of proceedings of the institution of civil engineers; 1922. p. $396-407$.

[6]

A.H. Gibson, Hydraulics and its applications, 1908, D. van Nostrand Company.

[7]

Wilson PN. A high speed impulse turbine; 1967

[8]

Webster J. Flow patterns related to jet-type impulse turbines; 1972.

[9]

Gilbert Gilkes \& Gordon Ltd. Improvements in water turbines. United Kingdom Patent; 1937.

[10]

Gilbert Gilkes \& Gordon Ltd. Improvements in water turbines. United Kingdom Patent; 1963.

[11]

J. Webster, Analysis of jet type impulse turbines, Water Power (August), 1971, P287-P292. 


\section{elsevier_APEN_7411}

[12]

J. Webster, Hydraulic impulse turbines of high specific speed, Water Power (July), 1973, P250-P260.

[13]

Harvey A. Micro-hydro design manual. In: Intermediate Technology Publications, editor. Warwickshire, UK; 1993.

[14]

Hartvigsen Hydro. Turgo Runners; 2015. <http://h-hydro.com/New_Site/turgo-runners/> [13/08/15].

[15]

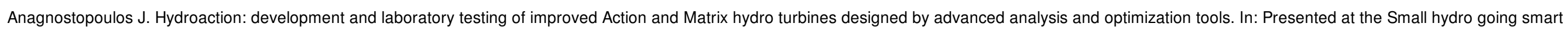
conference, Brussels; 2011.

[16]

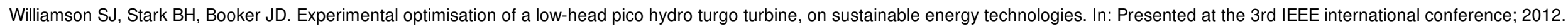

[17]

S.J. Williamson, B.H. Stark and J.D. Booker, Performance of a low-head pico-hydro turgo turbine, App/ Energy 102, 2013, 1114-1126.

[18]

S.J. Williamson, B.H. Stark and J.D. Booker, Low head pico hydro turbine selection using a multi-criteria analysis, Renewable Energy 61, $2014,43-50$.

[19]

S. Khurana, V. Kumar and A. Kumar, Effect of nozzle angle and silt parameters on erosion and performance of Turgo impulse turbine, Int J Therm Technol 2, 2012, 204-208.

[20]

S. Khurana, V. Kumar and A. Kumar, The effect of nozzle angle on erosion and the performance of Turgo impulse turbines, Int $J$ Hydropow Dams 2013.

[21]

S. Khurana, Varun and A. Kumar, Effect of silt particles on erosion of Turgo impulse turbine blades, Int J Ambient Energy 35, 2014, 155-162, [2014/07/03 2013].

[22]

S. Khurana and V. Goel, Effect of jet diameter on erosion of Turgo impulse turbine runner, J Mech Sci Technol 28, 2014, 4539-4546.

[23]

K. Gaiser, P. Erickson, P. Stroeve and J.-P. Delplanque, An experimental investigation of design parameters for pico-hydro Turgo turbines using a response surface methodology, Renewable Energy 85, $2016,406-418$.

[24]

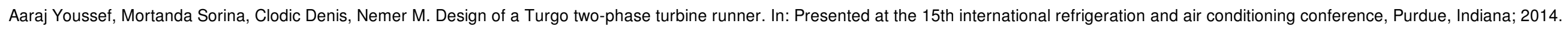

[25]

J.S. Anagnostopoulos and D.E. Papantonis, Flow modelling and runner design optimization in Turgo water turbines, World Acad Sci Eng Technol 28, 2007, 206-211.

[26]

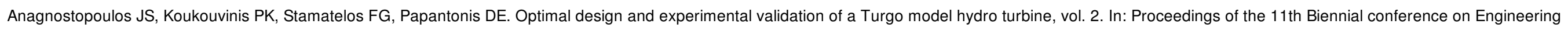
Systems Design and Analysis (ESDA), ASME, Nantes, France, July 2-4, 2012. p. 157-66. 


\section{elsevier_APEN_7411}

Koukouvinis P, Anagnostopoulos JS, Papantonis DE. SPH modelling of a Turgo turbine. SPHERIC newsletter 11th issue, December 2010.

[28]

P.K. Koukouvinis, J.S. Anagnostopoulos and D.E. Papantonis, SPH method used for flow predictions at a Turgo impulse turbine: comparison with fluent, World Acad Sci Eng Technol 5 (7), $2011,528-535$.

[29]

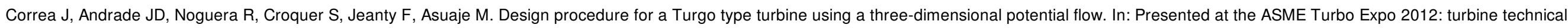
conference and exposition, Copenhagen, Denmark, June 11-15, 2012.

[30]

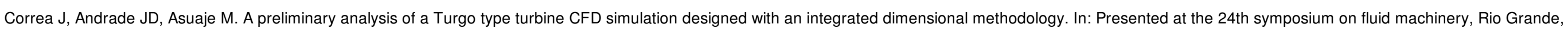
Puerto Rico, USA, July 8-12, 2012.

[31]

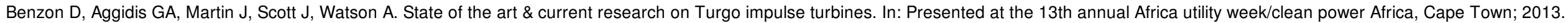

[32]

Benzon D. Using CFD in the analysis of Impulse turbines with a focus on the high capacity Turgo. In: Presented at the 14 th annual Africa utility week/clean power Africa, Cape Town; 2014.

[33]

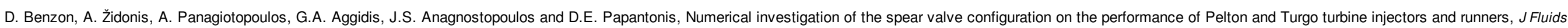
Eng 137, 2015, 111201-111201.

[34]

D. Benzon, A. Židonis, A. Panagiotopoulos, G.A. Aggidis, J.S. Anagnostopoulos and D.E. Papantonis, Impulse turbine injector design improvement using Computational Fluid Dynamics, ASME J Fluids Eng 2014.

[35]

Anagnostopoulos JS, Aggidis G, Papantonis DE. Parametric design and optimization of Turgo turbine runners. In: Presented at HYDRO 2015 conference, Bordeaux, France, October 22-24, 2015.

[36]

Foshan Xin Yi Hydropower Equipment Co. Ltd. Small hydro turbines; 2015. <http://www.smallhydroturbines.com/> [06/08/15]

[37]

Fuchun Industry Development Co. Ltd. Turgo turbine; 2015. <http://hydropowerturbine.sell.curiousexpeditions.org/c698796-turgo-turbine> [06/08/15] .

[38]

Wasserkraft Volk AG. Turgo turbines; 2015. <http://www.wkv-ag.com/en/produkte/turbinen-komplettanlagen/turgo-turbines.html> [06/08/15]

[39]

Gilkes. HCTI turbine design manual, ed. Pages from TDM 825 Turgo: Gilbert Gilkes and Gordon Ltd; 2012.

[40]

Evans Engineering. Tangenital flow turbines; 2015. <http://evans-engineering.co.uk/tangenital.cfm> [06/08/15]

[41]

Chongqing Hydropower Equipment Co. Ltd. Turgo turbine; 2015. <http://www.cchpe.net/Productlnfo.aspx?get=32> [06/08/15]. 


\section{elsevier_APEN_7411}

Hangzhou Hydrotu Engineering Co. Ltd., Turgo hydro turbine; 2015. <http://www.hydrotu.com/supplier-turgo_hydro_turbine-11597.html> [06/08/15].

\section{[43]}

Shandong Yaneng New Energy Equipment Co. Ltd. Turgo turbines; 2015. <http://sdyaneng.en.tradeatchina.com> [06/08/2015].

[44]

Tamar Hydropower Turbines. Turgo hydro turbines; 2015. <http://www.southerncross.pentair.com/Hydro_Turbines_and_Controls/turgo-hydro-turbines> [06/08/2015].

[45]

Shaoyang Hengyuan Zijiang Hydroelectric Equipment Co. Ltd. Turgo turbine; 2015. <http://www.syzjsd.com/en/products2.asp?id=644> [06/08/2015].

[46]

A. Zidonis, D. Benzon and G. Aggidis, Development of hydro impulse turbines and new opportunities, Renew Sustain Energy Rev 51, 2015, $1624-1635$.

Highlights

- Examines the Turgo operating range, principle and benefits over other turbine types.

- Presents the Turgo impulse turbine development from its invention until today.

- Reviews Turgo Pico-Micro \& Small-Medium scale turbine applications \& manufacturers.

- Highlights open issues for further research and development of the Turgo turbine.

- How modern tools for analysis and R\&D can be implemented for Turgo's next steps.

\section{Queries and Answers}

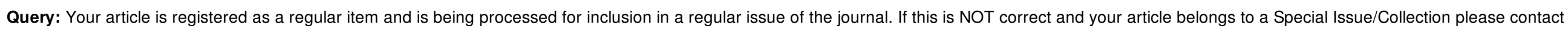
h.moorthy@elsevier.com immediately prior to returning your corrections.

Answer: YES THIS IS CORRECT

Query: The author names have been tagged as given names and surnames (surnames are highlighted in teal color). Please confirm if they have been identified correctly.

Answer: YES THESE ARE CORRECT

Query: The decimal comma has been changed to a decimal point in the term ' $4,5 \mathrm{~kW}$ '. Please check, and correct if necessary.

Answer: THANK YOU FOR THE CORRECTION

Query: Please check Refs. [13,21,25,39] have been set correctly.

Answer: Yes

Query: Please check the reference citations have been placed in Fig. 34 caption in order to crossref, and correct if necessary.

Answer: Yes 